\title{
KOMPARASI EFEKTIVITAS METODE PENGENDALIAN RAYAP Macrotermes gilvus DI PERKEBUNAN KELAPA SAWIT
}

\author{
Muhammad Ali Rafli $^{1 *}$, Sylvia Madusari ${ }^{1,2}$, Jojon Soesatrijo $^{3}$ \\ ${ }^{1}$ Program Studi Budidaya Perkebunan Kelapa Sawit, Politeknik Kelapa Sawit Citra \\ Widya Edukasi Jl. Gapura No. 8, Bekasi, Jawa Barat, 17520 \\ ${ }^{2}$ Program Studi Teknologi Produksi Tanaman Perkebunan, Politeknik Kelapa Sawit Citra \\ Widya Edukasi Jl. Gapura No. 8, Bekasi, Jawa Barat, 17520 \\ *E-mail: muhammadalirafli2@gmail.com
}

\begin{abstract}
ABSTRAK
Macrotermes gilvus merupakan rayap tanah dapat memberikan dampak negatif pada tanaman kelapa sawit karena mengganggu perakaran dan mengakibatkan tanaman tumbang sehingga perlu dikendalikan. Pengendalian hama rayap dapat dilakukan secara manual, kimia, dan biologi. Tujuan penelitian ini adalah membandingkan metode pengendalian rayap secara manual, kimia, dan biologi, dan menentukan efektivitas pengendalian melalui indikator kondisi sarang setelah pengendalian, keberadaan rayap pada tanaman kelapa sawit di sekitar sarang, waktu pengendalian, dan kebutuhan biaya. Penelitian menggunakan metode deskriptif komparatif dengan membandingkan efektivitas tiga metode pengendalian yaitu manual, kimia, dan biologi, melalui pengamatan terhadap waktu pengendalian dan perubahan volume sarang, serta biaya yang dibutuhkan. Metode manual dilakukan dengan cara menghancurkan sarang rayap dengan alat cados. Metode kimia dilakukan dengan menghancurkan sarang dan aplikasi termitisida berbahan aktif Fipronil 50 SC. Metode biologi dilakukan dengan melubangi sarang kemudian menginfeksi koloni dengan jamur Metarhizium anisopliae. Hasil penelitian menunjukkan bahwa berdasarkan parameter pertumbuhan sarang rayap, maka pengendalian secara kimia memperlihatkan hasil yang paling efektif. Namun demikian, pengendalian secara biologi menunjukkan tren penurunan laju pertumbuhan sarang rayap setelah proses pengendalian, dengan waktu pengendalian relatif lebih cepat ( $25 \mathrm{menit} / \mathrm{sarang}$ ) dan biaya (Rp. 28.505) yang realtif lebih rendah dibandingkan dengan cara kimia.
\end{abstract}

Kata kunci: Hama, Kelapa sawit, Rayap, Perkebunan.

\section{ABSTRACT}

Macrotermes gilvus is a termite soil that can harm oil palm crops because it interferes with rooting and causes yields to fall, so controlling it is crucial. Methods to control termite pest are manually, chemically, and biologically. The purpose of this study was to compare the manual, chemical, and biological termite control methods, and determine the effectiveness of control through indicators of nest conditions after management, the presence of termites in oil palm plants around the nest, control time, and cost needs. The research used comparative descriptive methods by comparing the effectiveness of three 
control methods by observing the control time and changes in nest volume, and the cost required. Cados tools used for controlling the termites' pest manually. The chemical procedure proceeds by destroying nests and applications of active-based termiticide Fipronil 50 SC. The biological process implemented by perforating the nest then infecting the colony with Metarhizium anisopliae. The results showed that based on termite nest growth parameters, chemical control showed the most effective results. However, biological control shows a downward trend in termite nests' growth rate after the control process, with relatively faster control time (25 minutes/ nest) and lower cost (Rp. 28.505) compared to chemical means.

Keywords: Pest, Oil Palm, Termite, Plantation.

\section{PENDAHULUAN}

Rayap merupakan mesofauna tanah utama di kawasan tropis. Rayap berperan penting dalam dekomposisi, perputaran unsur hara dan proses di dalam tanah (Pribadi, 2009). Jenis rayap yang terdapat di Indonesia antara lain Coptotermes curvignathus dan Macrotermes gilvus. Keduanya memiliki sifat perusak pada kayu, bangunan, dan material organik yang dapat menimbulkan dampak negatif berupa kerusakan, serta perkembangannya yang sangat cepat. Macrotermes gilvus memberikan pengaruh negatif apabila membuat koloni di dekat batang karena mengganggu perakaran dan mengakibatkan pohon tumbang (Pawana, 2016; Singham et al. 2017; Lee, 2013). Asosiasi Perusahaan Pengendalian Hama Indonesia (ASPPHAMI) menaksir kerugian ekonomis yang ditimbulkan oleh rayap secara nasional sekitar 2,8 triliun setiap tahunnya. Meliputi kerusakan pada perumahan, gedung, perkebunan dan kehutanan. (Pahlevi, 2018). Serangan rayap tanah dapat menyebabkan kerugian berupa penurunan hasil produksi hingga menyebabkan kematian pada tanaman inangnya. Oleh karena itu jika tidak dikendalikan akan dapat menimbulkan kerugian ekonomis yang sangat besar (Toni et al. 2015).

Upaya pengendalian hama Macrotermes gilvus di perkebunan kelapa sawit telah dilakukan. Secara umum proses pengendalian hama rayap dilakukan dengan metode manual, kimia, biologi, maupun kombinasi dari beberapa metode tersebut. Metoda manual merupakan metoda fisik, yaitu dengan menggunakan alat untuk merusak sarang rayap. Metode kimia adalah dengan menggunakan bahan kimia. Sedangkan metode biologi dilakukan dengan menggunakan organisme pengendali biologis yang dapat menghambat pertumbuhan rayap atau bahkan mematikan individu rayap. Jamur entomopatogen Metarhizium merupakan jamur yang banyak digunakan sebagai pengendali hayati. Desyanti et al. (2007) mengemukakan bahwa inokulasi jamur Metarhizium anisopliae mampu menyebabkan kematian pada rayap hingga $83,33 \%$.

Penelitian berkaitan dengan metode pengendalian rayap telah banyak dilakukan, namun demikian sangat sedikit penelitian yang membandingkan ketiga metode tersebut dengan variabel sejenis agar didapat data relevan sesuai dengan indikator efektivitas dengan aplikasi secara langsung di lapangan khususnya di perkebunan kelapa sawit. Tujuan dari penelitian ini adalah untuk menganalisis metode yang paling efektif dalam mengendalikan rayap di perkebunan kelapa sawit berdasarkan waktu pengendalian, laju pertumbuhan sarang rayap setelah pengendalian, dan gambaran biaya yang dibutuhkan pada periode tertentu. Pada penelitian ini diawali dengan sensus pengendalian, untuk mendapatkan data populasi 
serangan Macrotermes gilvus sebanyak $5 \%$ dari SPH 136. Sensus rayap dilakukan pada 2 sampel blok seluas 19,18 ha. Hal tersebut memperlihatkan bahwa jumlah serangan hama rayap telah melebihi ambang batas sehingga perlu dilakukan kajian untuk memberikan gambaran berkaitan dengan pengendalian hama rayap yang efektif, dan berkelanjutan.

\section{METODE}

Penelitian dilakukan di Blok F16 dan F17 Afdeling II, Estate Karusen, PT XYZ, Kabupaten Barito Timur, Provinsi Kalimantan Tengah.

Alat-alat yang digunakan dalam dalam penelitian ini yaitu: cados (cangkul dan dodos), palu, spidol, gunting, alat tulis, meteran, sarung tangan, knapsack sprayer $15 \mathrm{~L}$, parang, timbangan, botol, plastik, kamera, GPS, $\mathrm{pH}$ and moist meter, dan laptop. Penelitian dilakukan dengan menggunakan metode deskriptif komparatif, yaitu dengan menjelaskan cara dan hasil pengendalian ketiga metode yang mengacu pada indikator efektivitas.

Tahap pelaksanaan penelitian di antaranya: (a). Persiapan penelitian meliputi persiapan alat dan bahan, sensus serangan rayap di dalam blok, (b). pengukuran volume sarang, dan (c). identifikasi jenis hama rayap. Sensus dilakukan dengan metode sisir baris menggunakan instrumen sensus serangan hama. Pengukuran volume sarang dengan alat meteran, dan identifikasi menggunakan A Systematic Key to Termites of Thailand (Sornnuwat, 2004).

Pengendalian Macrotermes gilvus dengan metode manual, adalah metode pengendalian dengan cara menghancurkan sarang rayap menggunakan cados. Metode ini tidak menggunakan termitisida maupun jamur Metarhizium anisopliae sebagai bahan tambahan. Metode kimia, adalah metode pengendalian dengan cara menghancurkan sarang rayap menggunakan cados, kemudian mengaplikasikan termitisida Fipronil 50 SC menggunakan knapsack sprayer dengan dosis $60 \mathrm{cc} / \mathrm{sarang}$. Dosis tersebut merupakan dosis rekomendasi PT XYZ. Metode biologi dilakukan dengan melubangi sarang rayap kemudian menginfeksi koloni dengan jamur $50 \mathrm{gr}$ Metarhizium anisopliae/sarang. Dosis 50 gr/sarang merupakan dosis rekomendasi dari produk yang diperoleh secara komersil.

Pengamatan dilakukan pada indikator efektivitas yang telah ditentukan, yaitu pengamatan kondisi sarang setelah pengendalian dengan mengukur pertumbuhan volume dan memeriksa keberadaan rayap di tanaman sekitar sarang, perhitungan kebutuhan waktu yang telah ditentukan, yaitu $5,10,15$, dan 20 hari setelah aplikasi dan kebutuhan biaya alat dan bahan untuk pengendalian.

\section{HASIL DAN PEMBAHASAN}

\section{Identifikasi Jenis Rayap}

Jenis rayap tanah di Indonesia adalah dari famili Termitidae, yang memiliki sarang dalam tanah terutama dekat bahan organik yang memiliki kandungan selulosa seperti kayu, serasah, dan humus. Jenis rayap yang termasuk dalam famili Termitidae adalah Macrotermes spp. (Pramana et al. 2018 dan Pramana, 2016). Jenis rayap yang terdapat di perkebunan kelapa sawit PT XYZ adalah jenis Macrotermes gilvus. Konsep klasifikasi jenis rayap. Kasta prajurit mempunyai karakteristik berbeda pada ukuran, mandibel dan, kepala. Hasil identifikasi dilihat pada Gambar 1. 


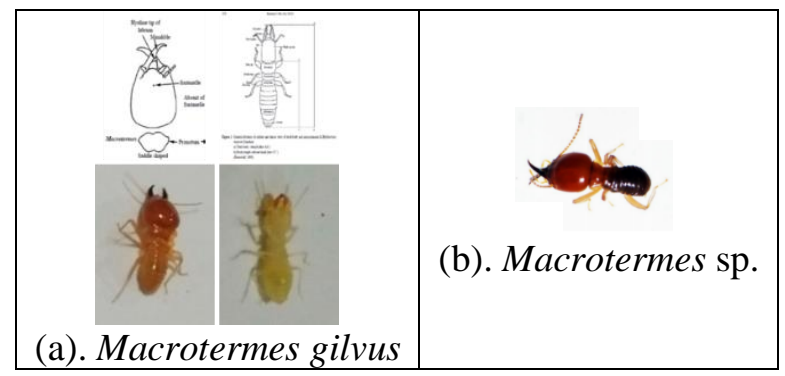

Gambar 1. (a). Identifikasi Macrotermes gilvus. Sumber: A Systematic Key to Termites of Thailand dari Sornnuwat (2014); (b). Macrotermes sp. (sumber: Rizali et al. 2020)

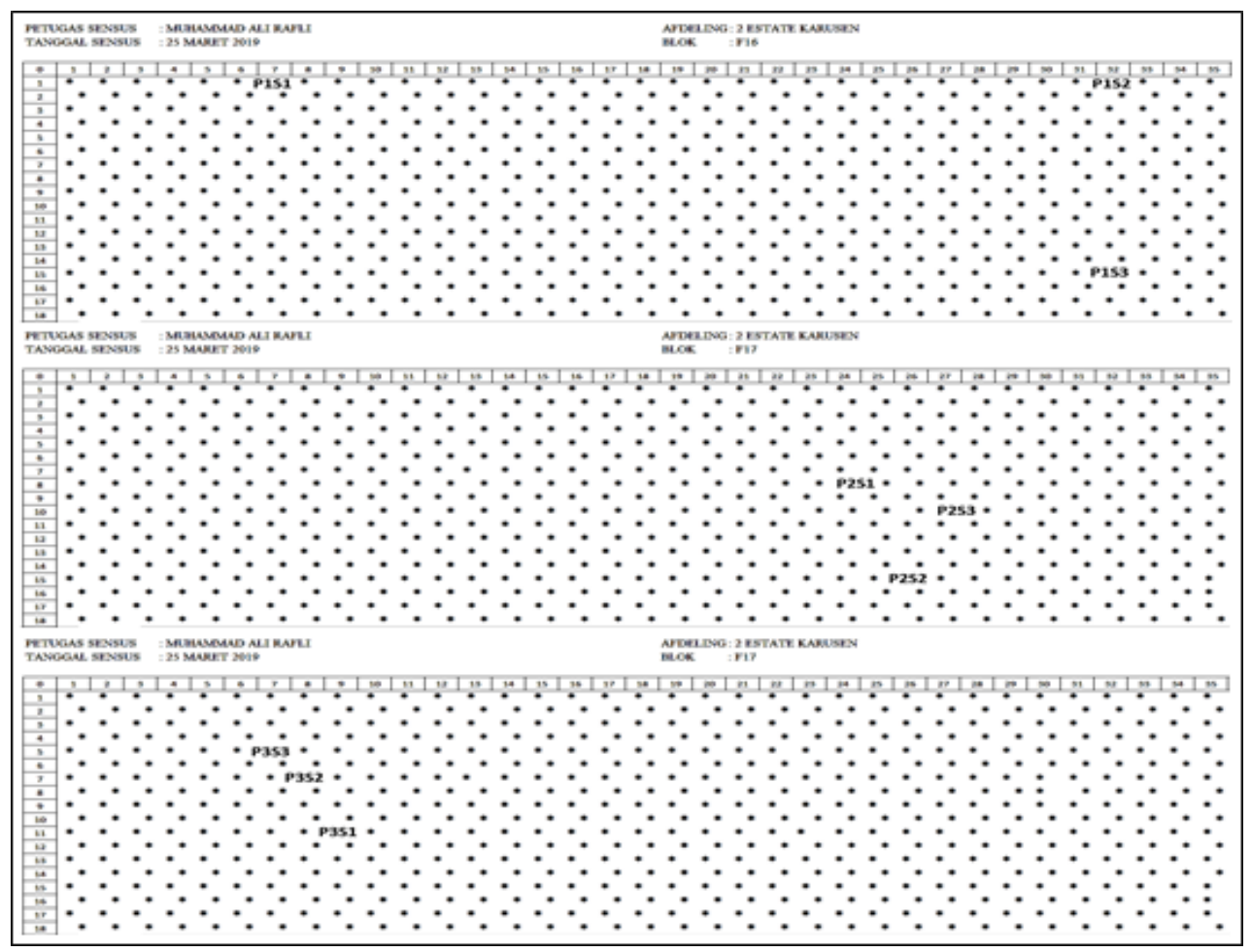

Gambar 2. Letak sampel penelitian

Tabel 1. Penomoran sampel dan volume sarang Macrotermes gilvus

\begin{tabular}{ccccccc}
\hline \multirow{2}{*}{ Nomor Sampel } & \multirow{2}{*}{ Jenis Perlakuan } & \multicolumn{4}{c}{ Ukuran (hari ke-0) } & \multirow{2}{*}{ Lokasi } \\
\cline { 3 - 6 } & & Panjang & Lebar & Tinggi & Volume & \\
P1S1 & Manual & 160 & 80 & 70 & 896,000 & F16 \\
P1S2 & Manual & 97 & 92 & 50 & 446,200 & F16 \\
P1S3 & Manual & 87 & 77 & 32 & 214,368 & F16 \\
P2S1 & Kimia & 80 & 72 & 50 & 288,000 & F17 \\
P2S2 & Kimia & 90 & 96 & 80 & 691,200 & F17 \\
P2S3 & Kimia & 84 & 98 & 52 & 428,064 & F17 \\
P3S1 & Biologi & 50 & 92 & 76 & 349,600 & F18 \\
P3S2 & Biologi & 65 & 128 & 95 & 790,400 & F19 \\
P3S3 & Biologi & 60 & 137 & 83 & 682,260 & F20 \\
\hline
\end{tabular}

M. gilvus memiliki ciri bentuk kepala persegi panjang, memiliki mandibel, dan memiliki pronotum (Sornnuwat, 2004). Ciri prajurit mayor $M$. gilvus adalah panjang kepala 3,25-3,65 $\mathrm{mm}$, lebar kepala 2,55-3,00 mm; panjang mandibel $1,60-1,190 \mathrm{~mm}$. Prajurit minor lebar kepala 1,37-1,60 mm; panjang kepala 
1,75-2,07 mm; panjang mandibel 1,22$1,37 \mathrm{~mm}$ (Subekti, 2008).

Jumlah sarang Macrotermes gilvus yang terdapat di areal penelitian seluas 19,18 ha adalah 127 sarang dengan ukuran yang berbeda dan menyebar menyebar di dalam sampel areal penelitian. Populasi sarang dihitung dengan sensus, yaitu dengan meyisir baris tanam yang terserang di dalam blok. Metode ini menggunakan Form sensus serangan rayap. Penentuan sarang sampel dilakukan dengan memperhatikan kerapatan populasi sarang di dalam blok. Letak sarang rayap dapat dilihat pada Gambar 2.

Pengukuran Volume Sarang dan Kondisi Sarang Setelah Pengendalian.

Sarang M. gilvus diberikan nomor sampel untuk memudahkan pengelompokkan dalam pengendalian. Sarang yang dijadikan sampel diukur volumenya untuk mengetahui pertumbuhan sarang tersebut setelah pengendalian. Penomoran sampel dan pengukuran volume sarang dapat dilihat pada Tabel 1, sedangkan pertumbuhan volume sarang setelah proses pengendalian dapat dilihat pada Tabel 2, Gambar 3, dan Gambar 4.

Respon sarang $M$. gilvus terhadap pengendalian dengan ketiga metode menunjukan hasil yang berbeda. Kondisi sarang $M$. gilvus setelah dikendalikan dengan ketiga metode dapat dilihat pada Tabel 2. Sarang M. gilvus yang dikendalikan dengan metode manual mengalami pertumbuhan volume kembali sejak 5 hari setelah pengendalian dan volume sarang cenderung terus meningkat hingga pengamatan hari ke20. Hal tersebut disebabkan oleh koloni rayap yang tidak mati secara menyeluruh apabila pengendalian dilakukan secara manual. Hal ini disebabkan karena dengan metode manual, kerusakan hanya terjadi pada sarang, namun rayap tidak mengalami kematian. Dapat dipastikan bahwa koloni rayap yang dikendalikan dengan metode ini cenderung akan bertahan hidup.

Sarang $M$. gilvus yang dikendalikan dengan metode kimia tidak terlihat mengalami pertambahan volume sarang. Hal tersebut dapat terjadi karena Macrotermes gilvus mati seluruhnya ketika proses pengendalian. Termitisida yang digunakan pada penelitian ini berbahan aktif Fipronil 50 SC dan aplikasi bahan tersebut memperlihatkan hasil yang efektif dalam mengendalikan hama rayap. Hal ini terlihat pada Gambar 3 , yaitu tidak terjadi penambahan volume sarang yang berarti menunjukkan bahwa rayap telah mati. Menurut Pawana (2016), Senyawa Fipronil merusak sistem saraf rayap, sehingga sistem saraf pada rayap tidak berfungsi dan rayap mengalami kematian. Hal tersebut sejalan dengan penelitian Tobing (2007), daya bunuh Fipronil sebagai insektisida mempengaruhi susunan saraf serangga dan daya racun kontak. Ketika rayap yang terkena infeksi, maka rayap tersebut akan menularkan racun ke anggota koloni lainnya melalui kontak langsung dari mulut dan sentuhan antar individu dalam koloni.

Tabel 2. Pertumbuhan sarang Macrotermes gilvus setelah dikendalikan

\begin{tabular}{|c|c|c|c|c|c|c|c|c|c|c|c|c|}
\hline \multirow[b]{2}{*}{$\begin{array}{l}\text { Nomor } \\
\text { Sampel }\end{array}$} & \multicolumn{3}{|c|}{ Hari 5} & \multicolumn{3}{|c|}{ Hari 10} & \multicolumn{3}{|c|}{ Hari 15} & \multicolumn{3}{|c|}{ Hari 20} \\
\hline & $\begin{array}{c}\mathrm{P} \\
(\mathrm{cm})\end{array}$ & $\begin{array}{c}\mathrm{L} \\
(\mathrm{cm})\end{array}$ & $\begin{array}{c}\mathrm{T} \\
(\mathrm{cm})\end{array}$ & $\begin{array}{c}\mathrm{P} \\
(\mathrm{cm})\end{array}$ & $\begin{array}{c}\mathrm{L} \\
(\mathrm{cm})\end{array}$ & $\begin{array}{c}\mathrm{T} \\
(\mathrm{cm})\end{array}$ & $\begin{array}{c}\mathrm{P} \\
(\mathrm{cm})\end{array}$ & $\begin{array}{c}\mathrm{L} \\
(\mathrm{cm})\end{array}$ & $\begin{array}{c}\mathrm{T} \\
(\mathrm{cm})\end{array}$ & $\begin{array}{c}\mathrm{P} \\
(\mathrm{cm})\end{array}$ & $\begin{array}{c}\mathrm{L} \\
(\mathrm{cm})\end{array}$ & $\begin{array}{c}\mathrm{T} \\
(\mathrm{cm})\end{array}$ \\
\hline P1S1 & 10 & 18 & 5 & 18 & 11 & 8 & 35 & 13 & 12 & 52 & 17 & 20 \\
\hline P1S2 & 14 & 12 & 6 & 20 & 15 & 10 & 28 & 20 & 13 & 47 & 25 & 18 \\
\hline P1S3 & 12 & 14 & 4 & 17 & 18 & 7 & 30 & 22 & 10 & 48 & 26 & 16 \\
\hline P2S1 & - & - & - & - & - & - & - & - & - & - & - & - \\
\hline $\mathrm{P} 2 \mathrm{~S} 2$ & - & - & - & - & - & - & - & - & - & - & - & - \\
\hline $\mathrm{P} 2 \mathrm{~S} 3$ & - & - & - & - & - & - & - & - & - & - & - & - \\
\hline P3S1 & 50 & 92 & 76 & 55 & 97 & 78 & 57 & 101 & 82 & 57 & 101 & 82 \\
\hline P3S2 & 65 & 128 & 95 & 72 & 138 & 110 & 75 & 140 & 114 & 78 & 140 & 114 \\
\hline P3S3 & 60 & 137 & 83 & 68 & 140 & 89 & 73 & 145 & 91 & 72 & 146 & 92 \\
\hline
\end{tabular}




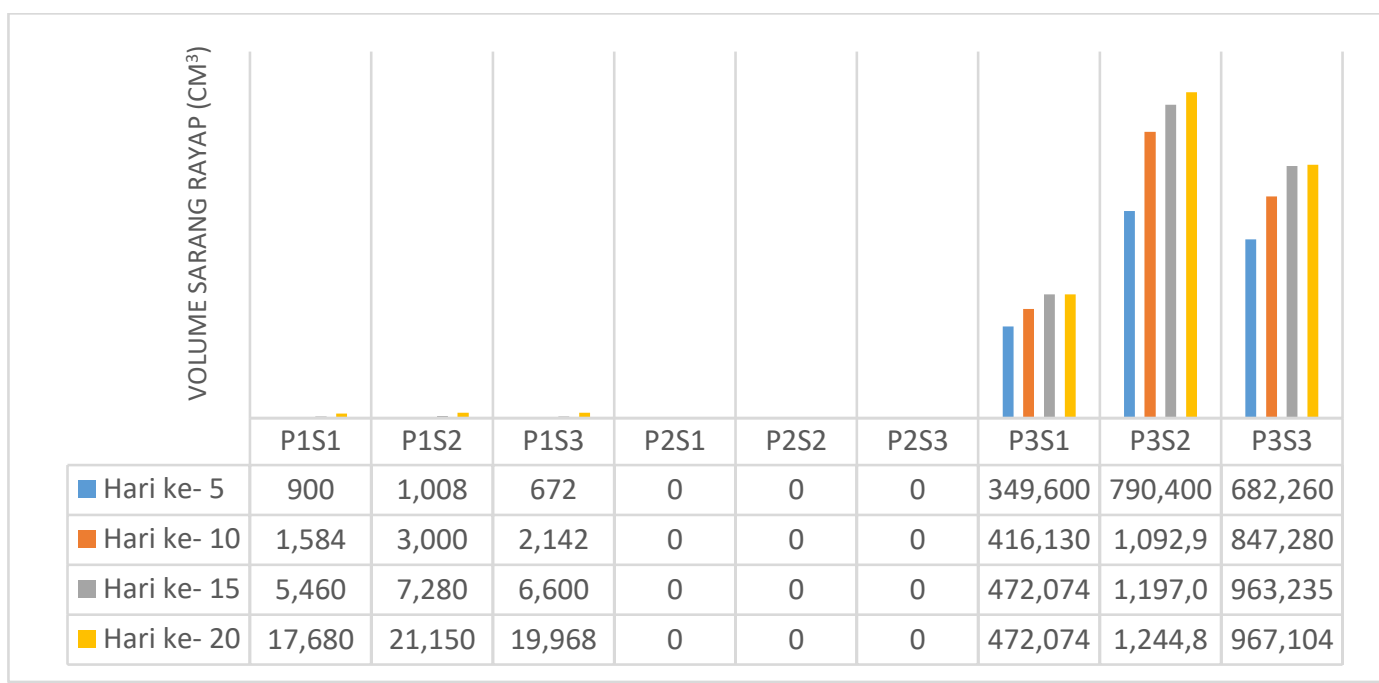

Gambar 3. Volume sarang setelah proses pengendalian secara manual, kimia, dan biologi.

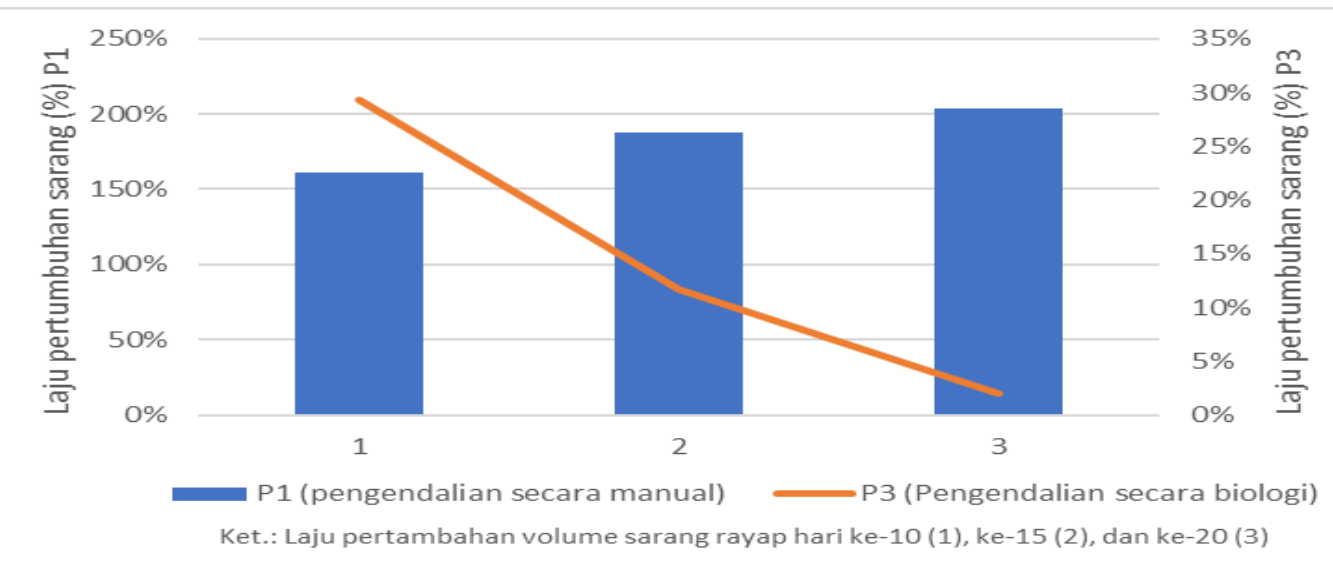

Gambar 4. Laju pertumbuhan volume sarang rayap setelah pengendalian secara manual dan biologi.

Pada Gambar 3 tampak bahwa sarang $M$. gilvus yang dikendalikan dengan metode biologi mengalami pertumbuhan volume pada hari ke-5 setelah aplikasi, serta menunjukkan kecenderungan meningkat pada pengamatan hari ke-10, hari ke-15 dan ke-20. Namun demikian, hal yang menarik adalah bahwa laju pertambahan volume sarang cenderung menurun, jika dibandingkan dengan pengendalian secara manual (Gambar 4). Laju yang menurun ini menunjukkan bahwa pengendalian secara biologi dapat dilakukan menggunakan jamur Metarhizium anisopliae. Hal ini memperlihatkan bahwa jamur tersebut memiliki potensi sebagai pengendali hayati, menggunakan organisme yang bersifat ramah lingkungan dapat dilakukan. Namun demikian, perlu dilakukan penelitian lebih lanjut untuk mendapatkan dosis yang efektif. Dampak dan pola yang terlihat pada penelitian ini dengan metode biologi, dapat terjadi terjadi karena koloni Macrotermes gilvus tidak terinfeksi seluruhnya. Penyebab infeksi yang tidak merata bisa disebabkan oleh tiga kemungkinan. Pertama, metode aplikasi yang kurang menyeluruh. kedua jumlah larutan dan dosis Metarhizium anisopliae terlalu sedikit, ketiga Rayap M. gilvus bergerak begitu cepat, sehingga jamur tidak mampu menginfeksi lebih dari kontak pertama.

Widiyanti dan Muyadihardja (2004), menyatakan cendawan Metarhizium 
anisopliae memiliki aktivitas larvisidal karena menghasilkan cyclopeptida, destruxin, dan desmethyldestrusin. Cendawan Metarhizium anisopliae menghasilkan endotoksin yang mematikan yaitu destruxins yang menyebabkan kelumpuhan dan kematian pada serangga antara tiga dan empat belas hari setelah infeksi, tergantung dari jenis dan ukuran. Kondisi sarang Macrotermes gilvus sebelum dan setelah dikendalikan dapat dilihat pada Gambar 5,6 , dan 7 .

Tabel 3. Kebutuhan waktu ketiga metode pengendalian

\begin{tabular}{|c|c|c|c|c|c|}
\hline $\begin{array}{c}\text { Metode } \\
\text { Pengendalian }\end{array}$ & Nomor Sampel & $\begin{array}{l}\text { Persiapan } \\
\text { Alat dan } \\
\text { Bahan } \\
\text { (menit) }\end{array}$ & $\begin{array}{l}\text { Penghancuran } \\
\text { Sarang (menit) }\end{array}$ & $\begin{array}{l}\text { Aplikasi Bahan } \\
\text { Tambahan } \\
\text { (menit) }\end{array}$ & Total Waktu (menit) \\
\hline \multirow{4}{*}{ Manual } & P1S1 & 3 & 12 & - & 15 \\
\hline & P1S2 & 4 & 9 & - & 13 \\
\hline & P1S3 & 3 & 10 & - & 13 \\
\hline & Rata-rata & 3.33 & 10.33 & - & 14 \\
\hline \multirow{4}{*}{$\begin{array}{c}\text { Kimia } \\
\text { Termitisida } \\
\text { Fipronil 50 SC }\end{array}$} & $\mathrm{P} 2 \mathrm{~S} 1$ & 6 & 10 & 10 & 26 \\
\hline & $\mathrm{P} 2 \mathrm{~S} 2$ & 7 & 12 & 12 & 31 \\
\hline & $\mathrm{P} 2 \mathrm{~S} 3$ & 6 & 11 & 10 & 27 \\
\hline & Rata-rata & 6.33 & 11.00 & 10.67 & 28 \\
\hline \multirow{4}{*}{$\begin{array}{c}\text { Biologi } \\
\text { Metarhizium } \\
\text { anisopliae }\end{array}$} & P3S1 & 6 & 7 & 10 & 23 \\
\hline & P3S2 & 7 & 9 & 12 & 28 \\
\hline & P3S2 & 7 & 8 & 9 & 24 \\
\hline & Rata-rata & 6.67 & 8.00 & 10.33 & 25 \\
\hline
\end{tabular}

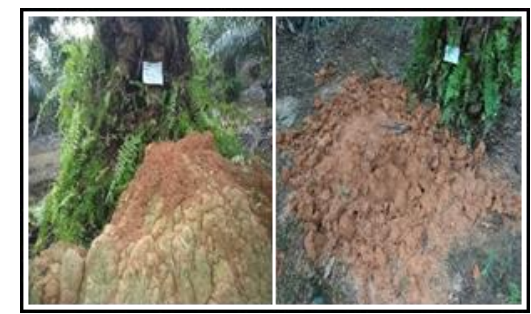

Gambar 5. Metode manual sebelum dan setelah dikendalikan.

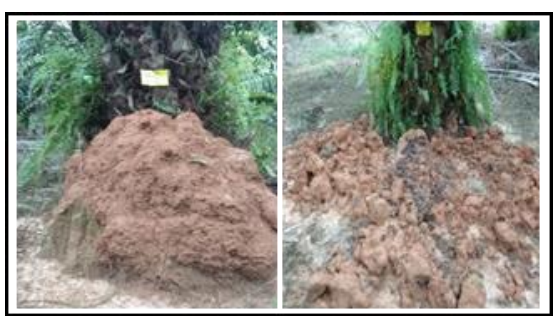

Gambar 6. Metode kimia sebelum dan setelah dikendalikan.

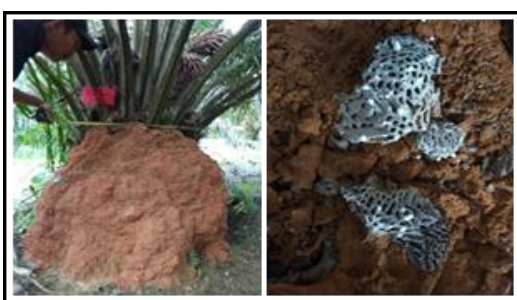

Gambar 7. Metode biologi sebelum dan setelah dikendalikan.

\section{Kondisi Tanaman Kelapa Sawit Di Sekitar Sarang}

Kondisi tanaman kelapa sawit yang berada di sekitar sarang $M$. gilvus dipastikan tidak mengalami gangguan (Gambar 8). Hal demikian terjadi karena tidak ditemukan adanya aktivitas dan keberadaan $M$. gilvus pada tanaman kelapa sawit. Koloni Macrotermes gilvus yang dikendalikan dengan metode manual tidak pergi ke tempat lain. Koloni Macrotermes gilvus yang dikendalikan dengan metode kimia mati seluruhnya, sehingga sangat kecil potensinya untuk berpindah dan membangun sarangnya di tempat lain.

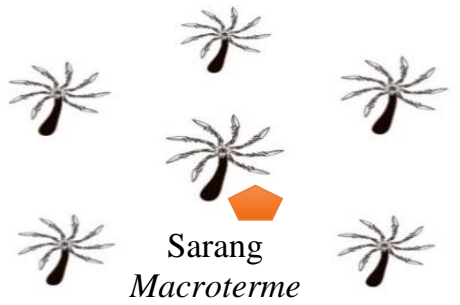

Gambar 8. merupakan letak tanaman kelapa sawit di sekitar sarang. 
Koloni $M$. gilvus yang dikendalikan dengan metode biologi terinfeksi oleh jamur. Meskipun tidak seluruhnya, koloni yang belum terinfeksi hanya memperbaiki sarangnya yang rusak dan tidak berpindah ke tempat lain. Selain itu, kecenderungan terhambatnya perkembangan volume sarang dapat diindikasikan bahwa jamur Metarhizium anisopliae dapat mengendalikan pertumbuhan rayap. Keppanan et al. (2018) dalam penelitiannya mengemukakan bahwa jamur Metarhizium anisopliae dapat menghambat perkembangan rayap, sehingga dapat digunakan sebagai bioinsektisida hayati berbasis jamur entomopatogen. Lebih lanjut dijelaskan bahwa jamur ini dapat mereduksi dampak negatif terhadap lingkungan, biaya rendah dalam produksinya dan ramah lingkungan.

\section{Kebutuhan Waktu}

Pengendalian $\quad M$ gilvus membutuhkan waktu pengerjaan yang berbeda. Hal itu disebabkan jumlah tahapan kerja yang berbeda pada pengendalian setiap metode. Pengendalian dengan metode kimia dan biologi membutuhkan waktu tambahan untuk pengaplikasian bahan yang digunakan. Pengaplikasian termitisida dan jamur Metarhizium anisopliae pada kedua pengendalian tersebut memerlukan waktu sekitar 10 menit (Tabel 3). Pengendalian dengan cara biologis menggunakan jamur memerlukan waktu proses penularan yang lama. Untuk menyelesaikan siklus hidupnya, maka jamur harus kontak dengan inangnya dan kemudian masuk kedalam inangnya dan bereproduksi dalam jaringan inang untuk menghasilkan propagule untuk kontak dan menginfeksi inang baru (Anggriawan et al. 2018). Ismanto dan Sukartana (2016) menjelaskan bahwa jamur Metarhizium dapat menyebabkan rayap kehilangan daya reproduksi pada ratu (betina) dan menyebaban penurunan anggota koloni secara bertahap. Lebih lanjut Ismanto dan Sukartana (2016) mengemukakan bahwa dosis aplikasi dan virulensi isolate Metarhizium mempengeraruhi kematian rayap. Kim et al. (2020) memperlihatkan dalam penelitiannya bahwa untuk meningkatkan daya patogenitas Metarhizium dalam mengendalikan rayap dapat dilakukan dengan kombinasi protease. Hasil penelitiannya menunjukkan tingkat mortalitas yang dihasilkan mencapai $75.8 \%$. Kebutuhan waktu pengendalian ke tiga metode dapat dilihat pada Tabel 3.

\section{Kebutuhan Biaya}

Kebutuhan biaya pengendalian $M$. gilvus dengan menggunakan metode manual, kimia, dan biologi membutuhkan biaya yang berbeda. Analisis kebutuhan biaya pengendalian dilihat pada Tabel 4. Waktu yang dibuthkan adalah 1 Rotasi (4 bulan), luas areal yang diamati 19,18 ha dengan $\mathrm{SPH}$ 136 tanaman, dan tingkat serangan yang terjadi adalah $5 \%$.

Pengendalian $M$. gilvus dengan metode manual tidak menggunakan bahan tambahan. Biaya yang dibutuhkan hanya upah untuk menghancurkan sarang sebesar Rp. 19.143,- /sarang (didapat dari kalibrasi upah 1 HK (Hari Kerja) Rp. 114.858,- dibagi 6 sarang, yaitu jumlah sarang yang mampu dihancurkan oleh 1 Tenaga kerja dalam $1 \mathrm{HK}$ ).

Kebutuhan biaya pengendalian $M$. gilvus dengan metode kimia adalah yang terbesar dibandingkan dengan kebutuhan biaya metode lain. Hal ini disebabkan karena terdapat biaya tambahan berupa kebutuhan alat knapsack sprayer dan termitisida Fipronil 50 SC. Total kebutuhan termitisida Fipronil 50 SC untuk pengendalian 1 sarang adalah 60 cc. Dosis tersebut didapat dari perkalian konsentrasi dengan jumlah air.

Kebutuhan biaya pengendalian $M$. gilvus dengan metode biologi (Rp. 28.505) terhitung lebih mahal dari 
metode manual (Rp. 19.413), namun lebih murah dari metode kimia (Rp. 36.331). Untuk mengendalikan 1 sarang rayap dibutuhkan 50 gram Metarhizium anisopliae yang disuspensikan ke dalam 5 liter air.

Tabel 4. Analisis biaya pengendalian Macrotermes gilvus

\begin{tabular}{|c|c|c|c|c|c|c|}
\hline $\begin{array}{c}\text { Metode } \\
\text { Pengendalian }\end{array}$ & Item & $\begin{array}{l}\text { Harga Satuan } \\
\text { (Rp) }\end{array}$ & Qty & Jumlah (Rp) & Keterangan & $\begin{array}{c}\text { Biaya per } \\
\text { Sarang } \\
\text { (Rp) }\end{array}$ \\
\hline \multirow[t]{2}{*}{ Manual } & Cados & 150,000 & 5 & 750,000 & $\begin{array}{l}\text { Biaya } \\
\text { investasi }\end{array}$ & \multirow{3}{*}{19,413} \\
\hline & Upah & 19,413 & 130 & $2,531,921$ & Standar & \\
\hline \multicolumn{2}{|c|}{ Total } & & & $3,281,921$ & & \\
\hline \multirow{4}{*}{$\begin{array}{c}\text { Kimia } \\
\text { Termitisida } \\
\text { Fipronil } 50 \mathrm{SC}\end{array}$} & Cados & 150,000 & 5 & 750,000 & $\begin{array}{l}\text { Biaya } \\
\text { investasi }\end{array}$ & \multirow{4}{*}{36,331} \\
\hline & Regent Fipronil & $280 / \mathrm{cc}$ & $7,825 \mathrm{cc}$ & $2,191,123$ & Bahan & \\
\hline & knapsack sprayer & 350,000 & 5 & $1,750,000$ & $\begin{array}{l}\text { Biaya } \\
\text { investasi }\end{array}$ & \\
\hline & Upah & 19,413 & 130 & $2,531,921$ & Standar & \\
\hline \multicolumn{2}{|c|}{ Total } & & & $7,223,044$ & & \multirow{5}{*}{28,505} \\
\hline \multirow{4}{*}{$\begin{array}{c}\text { Biologi Jamur } \\
\text { Metarhizium } \\
\text { anisopliae (MA) }\end{array}$} & Cados & 150,000 & 5 & 750,000 & $\begin{array}{l}\text { Biaya } \\
\text { investasi }\end{array}$ & \\
\hline & Jamur MA & $180 / \mathrm{gr}$ & $6,521 \mathrm{gr}$ & $1,173,816$ & Bahan & \\
\hline & Knapsack Sprayer & 350,000 & 5 & $1,750,000$ & $\begin{array}{l}\text { Biaya } \\
\text { investasi }\end{array}$ & \\
\hline & Upah & 19,413 & 130 & $2,531,921$ & Standar & \\
\hline \multicolumn{2}{|c|}{ Total } & & & $6,205,737$ & & \\
\hline
\end{tabular}

\section{SIMPULAN}

Pengendalian hama rayap menggunakan bahan kimia menunjukkan tingkat efektivitas yang tertinggi. Namun demikian pengendalian hayati menggunakan jamur Metharizium anosopliae sangat potensial sebagai agen pengendali hama rayap. Pola penurunan laju pertumbuhan sarang rayap yang ditunjukkan setelah proses pengendalian hayati, dengan waktu pengendalian relatif lebih cepat (25 menit/sarang) dan biaya (Rp. 28.505) yang relatif lebih rendah dibandingkan dengan cara kimia, dapat menjadi acuan untuk dilakukan penelitian lebih lanjut agar dapat lebih efektif pada implementasinya di lapangan.

\section{UCAPAN TERIMA KASIH}

Terima kasih kepada PT XYZ, Kabupaten Barito Timur, Provinsi Kalimantan Tengah yang telah memfasilitasi kegiatan ini sehingga penelitian ini dapat dilakukan.

\section{DAFTAR PUSTAKA}

Anggriawan, I., Tarmadja, S., Kristalisas, E.N. 2018. Uji efektivitas insektisida hayati, insektisida kimia, dan insektisida botani dalam mengendalikan hama rayap di perkebunan kelapa sawit. Jurnal Agromast. 3(1).

Desyanti, Hadi Y.S., Yusuf, S., Santoso, T. 2007. Keefektifan beberapa spesies cendawan entomopatogen untuk mengendalikan rayap tanah Captotermes gestri wasmann (Isoptera: Thinotermitidae) dengan metode kontak dan umpan. Jurnal Ilmu dan Teknologi Kayu Tropis 5(2):68-77

Ismanto, A., dan Sukartana, P. 2016. Uji efektivitas isolate jamur entomopatogen Metarhizium anisopliae (Metsch.) Sorokin terhadap rayap tanah pada pengujian di laboratorium dan lapangan. Jurnal Penelitian hasil Hutan 34(4):261268.

Keppanan, R., Sivaperumal, S., Aguila, L.C.R,, Hussain M., Bamisile, B.S., Dash, C.K., Wang, L. 2018. Isolation and characterization of Metarhizium 
anisopliae TK29 and its mycoinseticide effets against subterranean termite Coptotermes formosanus. Microbial Pathogenesis 123: 52-59.

Kim, H.O., Jeong, S.G., Choi, I.S., yang, J.E., Lee, K.H., Kim, J. Kim, J.C., Kim, J.S, Park, H.W. 2020. Mechanism of insecticidal action of Metarhizium anisopliae on adult Japanese pine sawyer beetles (Monochamus alternatus). ACS Omega 5:25312-25318.

Lee, C.Y. 2013. Urban forest insect pests and their management in Malaysia. 2013 International Symposium of Forest Health Management.

Pahlevi, B. A. 2018. The 12th pacific-rim termite research group (PRTRG). Asosiasi Perusahaan Pengendalian Hama Indonesia (ASPPHAMI).

Pawana, C. 2016. Pengukuran populasi rayap tanah Macrotermes gilvus dan teknik pengendaliannya menggunakan termitisida berbahan aktif Fipronil pada perkebunan kelapa sawit milik rakyat di kabupaten Mesuji Lampung. Skripsi. IAIN Raden Intan, Lampung.

Pramana, A. 2016. Penggunaan Oli dan Insektisida Untuk Mengendalikan Rayap di Perkebunan Kelapa Sawit. Jurnal Agrosains dan Teknologi. 1(2): 64-72

Pramana, A., Haitami, A., Jamalludin. 2018. Identifikasi Hama Rayap Kelapa Sawit di Desa Simpang Raya Kabupaten Kuantan Singingi. Jurnal Agroteknologi Universitas Andalas. 2(1): 6-9

Pribadi, T. 2009. Keanekaragaman komunitas rayap pada tipe penggunanaan lahan yang berbeda sebagai bioindikator kualitas lingkungan. Tesis. Sekolah Pascasarjana Institut Pertanian Bogor, Bogor.
Rizali, A., Karindah, S., Windari, A., Rahardjo, B.T., Sahari, N.B. 2020. Ant and termite diversity in Indonesia oil palm plantation: investigating the effect of natural habitat existence. Biodiversitas. 21(4):1326-1331

Singham, G.V., Othman, A.S., Lee, C.Y. 2017. Phylogeography of the termite Macrotermes gilvus and insight into ancient dispersal corridors in Pleistocene Southeast Asia. Journal PloS ONE. 12(11): 1-22 https://doi.org/10.1371/journal.pone. 0186690

Sornnuwat, Y., Vongkaluang, C., Takematsu, Y. 2004. A Systematic Key To Termites of Thailand. Kasetsart J. (Nat. Sci.) 38 : 349 - 368.

Subekti, N., Duryadi, D., Nandika, D., Surjokusumo, S., Anwar, S. 2008. Sebaran dan karakter morfologi rayap tanah Macrotermes gilvus Hagen di habitat hutan alam. Jurnal Ilmu dan Teknologi Hasil Hutan 1(1):27-33. Institut Pertanian Bogor. Bogor.

Tobing, D. R. L. 2007. Penggunaan berbagai konsentrasi khitosan dan Fipronil terhadap pengendalian hama rayap tanah Macrotermes gilvus Hagen (isopteran; termitidae) di laboratorium. Skripsi. Fakultas Pertanian Departemen Ilmu Hama dan Penyakit Tumbuhan Universitas Sumatra Utara, Medan.

Toni, I., Diba, F., Nurhaida. 2015. Pengendalian Rayap Coptotermes curvignathus Holmgren dengan Umpan Rayap Hexaflumuron Bentuk Briquette pada Perkebunan Kelapa Sawit (Elaeis guineensis Jacq.) . Jurnal Hutan Lestari. 4(1):9-20

Widiyanti, N. L. P. M., Muyadihardja, S. 2004. Uji toksisitas Metarhizium anisopliae terhadap larva nyamuk Aedes aegypti. Media Litbang Kesehatan 14(3). 